\title{
BIOACCUMULATION OF AUTO-MECHANIC WASTES IN THE TISSUES OF Pellonula afzeliusi (Johnels, 1954) COLLECTED FROM AGBA STREAM ILORIN, KWARA STATE, NIGERIA
}

\author{
Adeyemi-Ale, O. A. ${ }^{1}{ }^{*}$, Oladipo, S. O. ${ }^{2}$ and Abdulkareem, S. I. ${ }^{1}$ \\ ${ }^{1}$ Department of Zoology, Faculty of Life Sciences, University of Ilorin, Ilorin, Kwara State, Nigeria. \\ ${ }^{2}$ Department of Biosciences and Biotechnology, Kwara State University, Malete, Kwara State, Nigeria. \\ * E-mail of corresponding author: adewoyin.oa@unilorin.edu.ng \\ (Received: $22^{\text {nd }}$ December, 2020; Accepted: $4^{\text {th }}$ June, 2021)
}

\section{ABSTRACT}

\begin{abstract}
Hydrocarbons and heavy metals (HM) present in automobile wastes get into water bodies close to automobile mechanic villages. They deteriorate the physico-chemical qualities of such water bodies and exert toxic effects on fish and other aquatic fauna. They also pose risks to humans that consume fish from streams near such automechanic villages. There is paucity of information on the HM contents of Agba stream, Ilorin and no information on the bioaccumulation of HM in the tissues of Pellonula afzeliusi is currently available. The purpose of this study was to assess the physico-chemical qualities of water and bioaccumulation of HM in the tissues of Pellonula afzeliusi fish collected from Agba stream, Ilorin, Kwara State, Nigeria. Water and samples of Pellonula afzeliusi were collected from the upstream (station A), midstream (station B) of Agba stream located close to an auto-mechanic village and Oyun dam (control site, station C) located within the University of Ilorin. Standard methods were used to analyse oil and grease (OG), total petroleum hydrocarbon (TPH) and HM in water samples. The concentrations of TPH and HM were analysed in the skin, bone, muscle, gills, gastrointestinal tract, liver and kidney of the fish. The order of water $\mathrm{HM}$ concentrations indicated $\mathrm{Zn}>\mathrm{Cd}>\mathrm{Ba}>\mathrm{Fe}>\mathrm{Pb}$ at station $\mathrm{A}$; $\mathrm{Cd}>\mathrm{Zn}>\mathrm{Fe}>\mathrm{Ba}>\mathrm{Pb}$ at station $\mathrm{B}$, and $\mathrm{Zn}>\mathrm{Ba}>\mathrm{Pb}>\mathrm{Fe}>\mathrm{Cd}$ at station $\mathrm{C}$. TPH and $\mathrm{HM}$ bioaccumulated in the tissues of fish while lead was not detected in all tissues from station C. Bioaccumulation factor varied with the highest values at station $\mathrm{C}$. The result of this study indicated heavy pollution burden in station B with lower pollution burden in station C (the control site). These call for attention of government in ensuring ecological restoration and prevention of further discharge of automobile wastes into the stream.
\end{abstract}

Keywords: Automobile wastes, Heavy metals, Hydrocarbons, Bioaccumulation, Pellonula afzeliusi

\section{INTRODUCTION}

In recent times, there is an increase in the discharge of automobile wastes through motor servicing centers popularly known as automechanic workshops. Petrol, diesel, solvents, grease, and lubricants are accidentally or deliberately discharged from the auto-mechanic workshops on to the land (Adewoyin et al., 2013). The release of these fossil fuel products on the land, leads to the accumulation of heavy metals in the soil and leaching to nearby wells and streams, thus bringing about biological threats and adverse environmental impacts to the nearby ecosystem (Adelekan and Abegunde, 2011; Utang et al., 2013).

The large-scale spilling of petroleum products has been recognized as a serious environmental problem because used engine oil picks up a number of additional compounds like heavy metals from engine wear (Horsfall, 2011; Popoola and Ayodele, 2016). These additives and contaminants make used oil disposal to be more environmentally damaging than crude oil (Abioye et al., 2012). Due to the bioaccumulation and toxic tendency of heavy metals (El-Nagger et al., 2009), they are considered to be the most hazardous environmental pollutants (Al-Attar, 2005).

The increase in anthropogenic activities such as the auto-mechanic servicing activities brings a growing concern over the ecological effects of accumulation of heavy metals in the environment bringing about significant effects on the trophic chain, plants, animals and man (Campbell et al., 2005). Hence, deterioration of water quality and a steep degradation of freshwater biodiversity habitats are experienced (Nevoh et al., 2015).

Streams and reservoirs are invaluable ecological resources that serve many human needs domestically, industrially and ecosystem wise (Oladipo et al., 2018). Oyun and Agba reservoirs in Ilorin were constructed to serve the purposes of irrigation, domestic water supply and fish farming. 
Fishes are aquatic inhabitants that are unable to get rid of the lethal effects of various pollutants in natural waters (Olaifa et al., 2004). They have been recognized as suitable bio-indicator for the assessment of heavy metal contamination in aquatic systems due to the ease of accumulation through uptake of metals in water and diet (Papagiannis et al., 2004; Izegaegbe and Oloye, 2017). These metals can bioaccumulate in the tissues of fish. The beneficial effects of fish consumption can be compromised by the presence of toxic heavy metals in them (Bawuro et al., 2018).

Pellonula afzeliusi are small-toothed, herring-like fishes belonging to the family Clupidae, and distributed in West African rivers and man-made lakes (Ikusemiju et al., 1983). They are pelagic (Froese and Pauly, 2019), and their diet include crustaceans, Ephemeropteran nymphs, chironomids, fishes, plant detritus and sand grains (Ikusemiju et al., 1983; Ezenwaji and Offiah, 2004). Pellonula afzeliusi is the dominant fish in Agba stream and residents around the stream collect and consume the fish. There is paucity of information on the heavy metal contents of Agba stream, Ilorin and no information on the bioaccumulation of heavy metals in the tissues of Pellonula afzeliusi. Therefore, there is need to assess the level of heavy metals in Agba stream, their concentrations and bioaccumulation levels in Pellonula afzeliusi inhabiting the stream.

\section{MATERIALS AND METHODS \\ Description of the Study Sites}

Agba Stream ( $8^{\circ} 47^{\prime} 0^{\prime \prime} \mathrm{N}, 4^{\circ} 56^{\prime} 0^{\prime \prime}$ E) located in Ilorin South Local Government Area, Kwara State, Nigeria (Figure 1) flows out from Agba dam. It flows through the side of an auto-mechanic village. The upstream with no influence of automechanic activities was designated as station $\mathrm{A}$, while the point where auto-mobile wastes are directly dumped or sipped into the stream, located about $500 \mathrm{~m}$ from station $\mathrm{A}$ was designated as station B. Oyun dam (8²8'10” N, 4 39'50” E) located at the University of Ilorin, Kwara State was taken as the control site (station $\mathrm{C}$ ) because it is apparently free from the influx of pollutants.

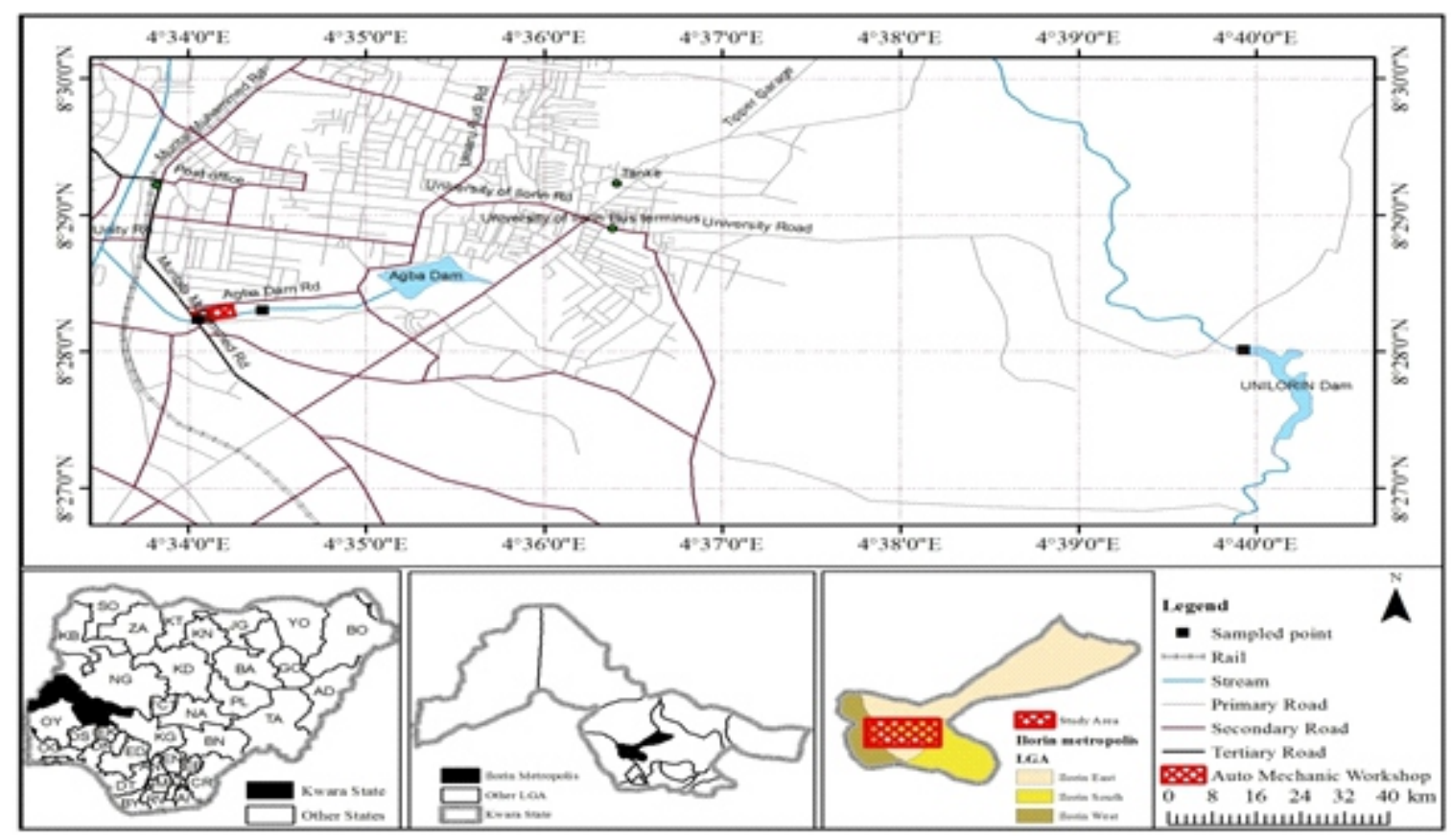

Figure 1: Map of the Study Sites Showing Agba stream and Oyun (UNILORIN) Dam 


\section{Water Sampling and Analysis}

Water samples were collected in the early hours between 7:00 am to 9:00 am in the month of March 2018. The samples were analysed for physico-chemical qualities such as oil and grease (OG), total petroleum hydrocarbon (TPH) and heavy metals $(\mathrm{HM})$ such as iron $(\mathrm{Fe})$, zinc $(\mathrm{Zn})$, cadmium $(\mathrm{Cd})$, barium $(\mathrm{Ba})$ and lead $(\mathrm{Pb})$.

Water samples for the analysis of OG and TPH were collected in one-litre amber glass bottles with Teflon-lined screw caps. The samples were immediately filtered and preserved with concentrated $\mathrm{HCl}$ and held at $4{ }^{\circ} \mathrm{C}$ until extracted within 14 days of collection. The water samples for $\mathrm{HM}$ analysis were collected in $500 \mathrm{ml}$ reagent bottles and were immediately preserved with 0.75 $\mathrm{ml}$ of concentrated nitric acid $\left(\mathrm{HNO}_{3}\right)$ prior to digestion and further analysis (APHA, 2012). The hexane extractable gravimetric method, (EPA 1664B extraction technique, 2010) was used for the determination of $\mathrm{OG}$ and TPH while samples for HM digestion and analysis were according to the standard procedures of American Public Health Association (APHA, 2012).

\section{Preparation, Extraction and Analyses of OG and TPH}

In the laboratory, the samples were adjusted to a $\mathrm{pH}<2$ with concentrated $\mathrm{HCl}$. The samples were brought out to room temperature. In a $500 \mathrm{ml}$ separating funnel, $350 \mathrm{ml}$ of sample was added. Five (5) boiling chips were added to $125 \mathrm{ml}$ distillation flask and the flask was weighed. For extraction, $20 \mathrm{ml}$ n-hexane was added to the separating funnel; the stopper was put and inverted. This was vigorously shaken for 2 minutes. It was left to stand for 10 minutes to separate the lower water layer and the upper solvent. The lower water layer was drained into a $500 \mathrm{ml}$ volumetric flask for about $4 \mathrm{~min}$. Ten grams (10 g) of anhydrous sodium sulphate $\left(\mathrm{Na}_{2} \mathrm{SO}_{4}\right)$ was added to a folded filter paper in the filtering funnel. The $\mathrm{Na}_{2} \mathrm{SO}_{4}$ was rinsed with a small amount of n-hexane and the $n$-hexane was discarded. Through the funnel that contains filter paper and $10 \mathrm{~g} \mathrm{Na}_{2} \mathrm{SO}_{4}$, the solvent layer was dripdrained into the pre-weighed boiling flask and the water layer was returned to the separating funnel. The extraction procedure was repeated two more times.
The separating funnel was rinsed with three different $5 \mathrm{ml}$ aliquots of fresh $\mathrm{n}$-hexane to remove oil film that stayed on the funnel walls. Each aliquot was drained into the distillation flask through the funnel that contains $\mathrm{Na}_{2} \mathrm{SO}_{4}$. After this, distillation process was carried out and completed within $28 \mathrm{~min}$. A vacuum connector was attached and vacuum applied for $2 \mathrm{~min}$ to remove the remaining $\mathrm{n}$-hexane solvent vapors from the distillation flask. The distillation flask was put in a desiccator until the flask temperature decreases to room temperature and subsequently the flask was weighed.

OG was calculated using the formula:

$$
\frac{A-B}{\text { Sample volume }} \times 100=m g / L O \& G
$$

A - Weight ( $\mathrm{mg}$ ) of residue

$\mathrm{B}$ - Weight (mg) of flask with boiling chips

\section{TPH Analysis}

The residue was dissolved with $25 \mathrm{ml}$ of fresh $\mathrm{n}$ hexane and heated slightly. The dissolved residue was poured into $100 \mathrm{ml}$ volumetric flask and made up to volume with $\mathrm{n}$-hexane and properly mixed. Silica gel $(3 \mathrm{~g})$ was added and the solution was stirred on a magnetic stirrer for $5 \mathrm{~min}$. A funnel was put on a clean dry distillation flask with 5 boiling chips. A filter paper was pre-moistened with fresh $\mathrm{n}$-hexane, placed in the funnel and the solution was filtered. The volumetric flask with the remaining silica gel was rinsed with $5 \mathrm{ml}$ aliquots of fresh $n$-hexane and the aliquots was poured into the distillation flask, then the distillation process was carried out. The remaining product at the bottom of the flask was weighed and TPH was calculated using the formula:

\section{$\frac{A-B}{\text { Sample volume }}=m g / L T P H$}

A - Weight (mg) of residue

B - Weight ( $\mathrm{mg}$ ) of flask with boiling chips

\section{Heavy Metals Analysis}

Ten millilitres $(10 \mathrm{ml})$ concentrated nitric acid and $5 \mathrm{ml}$ concentrated perchloric acid were added to $20 \mathrm{ml}$ of water sample in a $100 \mathrm{ml}$ Erlenmeyer flask. This was allowed to mix thoroughly and the mixture was evaporated to 2 to $5 \mathrm{ml}$ on a hot plate until a clear solution was obtained. It was made up 
to volume with double distilled water. Each heavy metal was analysed with graphite furnace Atomic Absorption Spectrophotometer (AAS Model Agilent Aa55).

\section{Fish Sampling and Analysis}

Fish samples $(\mathrm{n}=30$; average length $=12.03 \pm 0.32$ $\mathrm{cm}$; average weight $=16.3 \pm 0.5 \mathrm{~g}$ ) were collected in the early hours between 7:00 am to 9:00 am in the month of March, 2018. Fish samples were collected using hook and line, and cast net $(3 / 8$ inches mesh size) with the help of local fishermen. All the specimens of Pellonula afzeliusi were kept in a water container and transported to the laboratory of the Department of Zoology, University of Ilorin, Nigeria. Specimens were identified following the identification keys provided by Olaosebikan and Raji (1998) and Idodo-Umeh (2003). Five fish were randomly picked for analysis. The length of the fish selected ranged from $10-15 \mathrm{~cm}$ while their weights measured between $13.90-20.10 \mathrm{~g}$.

In the laboratory, the fish was dissected and the skins, bones, muscles, gills, gastrointestinal tract, liver and kidney removed. They were then transferred into different bottles containing 0.25 $\mathrm{ml}$ sucrose solution $(1: 5 \mathrm{wt} / \mathrm{vol})$ and then homogenized with mortar and pestle. After homogenization, they were transferred back into the bottles containing sucrose solution.

\section{Fish TPH Analysis}

TPH concentrations were determined following the method of Ikpe et al. (2016). TPH extracting solvent $(1: 1 \mathrm{v} / \mathrm{v}$ of acetone and dichloromethane) was prepared. Twenty-five millilitres $(25 \mathrm{ml})$ each of acetone and dichloromethane were measured into $100 \mathrm{ml}$ volumetric flask and mixed properly. Then, $0.5 \mathrm{~g}$ of each homogenized tissue sample was weighed into a $50 \mathrm{ml}$ beaker and $30 \mathrm{ml}$ of the extracting solvent was added. The fish TPH content was extracted by shaking method according to Schwab et al. (1999). The beaker with the content was placed on a magnetic stirrer and shaken for about $10 \mathrm{~min}$ at $70{ }^{\circ} \mathrm{C}$. The extract was decanted into a clean round bottom flask, $10 \mathrm{ml}$ of fresh solvent was added, and the process repeated. The extracts were combined, and $1 \mathrm{~g}$ of anhydrous sodium sulphate was added to remove water. The extract was concentrated to $3 \mathrm{ml}$ with rotary evaporator maintained at $20{ }^{\circ} \mathrm{C}$ (Webster et al.,
1997).

\section{Analysis of Heavy Metals}

The concentrations of heavy metals in the tissues were digested and analysed following the method described by Du Preez and Steyn (1992). Briefly, $0.1 \mathrm{~g}$ of each fish tissue sample was weighed into $100 \mathrm{ml}$ Erlemenyer flask into which $10 \mathrm{ml}$ concentrated nitric acid and $5 \mathrm{ml}$ perchloric acid were added. Digestion was done on a hotplate (200 to $250{ }^{\circ} \mathrm{C}$ ) for about 4 hours during which there was total digestion and clear samples obtained. Each digested sample was filtered through filter paper. The filter system was rinsed with double distilled water to remove traces of the dissolved metal. Each sample was then made up to volume with the distilled water. An analytical blank was also prepared in a similar manner. Each heavy metal was analysed using a graphite furnace Atomic Absorption Spectrophotometer (AAS Model Agilent AA55).

\section{Calculation of bioaccumulation factor (BAF):}

$$
A F=\frac{[X]_{\text {organism }}}{[X]_{\text {water }}}(\text { USEPA, 2003) }
$$

Where

$[X]_{\text {organism }}$ is the concentration of the metal $\mathrm{X}$ in the tissue of the organism

$[X]_{\text {water }}$ is the concentration of the metal $\mathrm{X}$ in the water

BAF values less than 250 were scored 1 (low concern), values from 250 - 1000 were assigned 2 (medium concern) and 3 (high concern) was assigned to values greater than 1000 (waste minimization prioritization tool (WMPT) (USEPA, 2003).

\section{Statistical Analysis}

All statistical analysis was carried out using IBM SPSS version 21. The means and standard error of the means of the physico-chemical parameters of water were calculated. The bioaccumulation of TPH and HM in the fish tissues were also computed. ANOVA (Analysis of variance) and Duncan's multiple range tests were used to test for statistical $(\mathrm{P}<0.05)$ differences of physicochemical parameters of water, TPH and HM bioaccumulation in fish samples of the stations. 


\section{RESULTS AND DISCUSSION}

The assessment of TPH, OG and HM in this study showed high contributions of automechanic wastes to the environment. Concentrations of heavy metals in the water samples from Agba stream at station A and station $\mathrm{B}$, and the reference site (station $\mathrm{C}$ ) reflected the order of metal concentration as follows: $\mathrm{Zn}>\mathrm{Cd}$ $>\mathrm{Ba}>\mathrm{Fe}>\mathrm{Pb}$ at station $\mathrm{A}, \mathrm{Cd}>\mathrm{Zn}>\mathrm{Fe}>\mathrm{Ba}$ $>\mathrm{Pb}$ at station $\mathrm{B}$, and $\mathrm{Zn}>\mathrm{Ba}>\mathrm{Pb}>\mathrm{Fe}>\mathrm{Cd}$ at station $\mathrm{C}$. All the heavy metal contents of the station $\mathrm{C}$ were significantly $(\mathrm{P}<0.05)$ different from stations $A$ and $B$, except that of zinc of station A. The TPH and OG contents of water samples from stations $\mathrm{A}$ and $\mathrm{B}$ exceeded the standard permissible limits of $10 \mathrm{mg} / \mathrm{L}$ and 0.1 $\mathrm{mg} / \mathrm{L}$ by Environmental Guidelines and
Standards for the Petroleum Industry in Nigeria (EGASPIN, 2002) and National Environmental Standards and Regulatory Enforcement Agency (NESREA, 2011) respectively. All the HM concentrations of the water samples from station B exceeded the NESREA (2011) allowable limits (Table 1). Out of all the metals measured in the three stations, $\mathrm{Zn}$ concentrations were mostly elevated and $\mathrm{Cd}$ concentration obtained from station B. The increase in mean concentration of heavy metals in the samples could be attributed to metal concentration from the auto-mechanic wastes together with reduction in water volume during the period of sampling which coincided with the peak period of dry season. Similar observation in Bradford Beck catchment, West Yokshire was reported by Goodwin et al. (2003).

Table 1: Total Petroleum Hydrocarbon, Oil and Grease and Heavy Metals Concentrations (mg/L) of Water Samples from Agba stream and Oyun dam, Ilorin, Nigeria

\begin{tabular}{|c|c|c|c|c|}
\hline Parameters & Station A & Station B & Station C & NESREA Limit \\
\hline TPH & $138.6000 \pm 0.0577^{\mathrm{b}}$ & $153.4000 \pm 0.0577^{\mathrm{c}}$ & $9.0820 \pm 0.0006^{\mathrm{a}}$ & - \\
Oil and G & $350.0000 \pm 0.5774^{\mathrm{b}}$ & $1000.0000 \pm 0.0000^{\mathrm{c}}$ & $0.0070 \pm 0.5774^{\mathrm{a}}$ & 0.1 \\
Iron (Fe) & $0.1300 \pm 0.0000^{\mathrm{b}}$ & $0.8067 \pm 0.0088^{\mathrm{c}}$ & $0.0227 \pm 0.0001^{\mathrm{a}}$ & 0.5 \\
Zinc (Zn) & $0.6700 \pm 0.0056^{\mathrm{ab}}$ & $1.0000 \pm 0.0000^{\mathrm{b}}$ & $0.1200 \pm 0.0058^{\mathrm{a}}$ & 0.2 \\
Cadmium (Cd) & $0.0900 \pm 0.0056^{\mathrm{b}}$ & $1.2000 \pm 0.0577^{\mathrm{c}}$ & $0.0130 \pm 0.0000^{\mathrm{a}}$ & 0.01 \\
Barium (Ba) & $0.3000 \pm 0.0056^{\mathrm{b}}$ & $0.5200 \pm 0.0058^{\mathrm{c}}$ & $0.1000 \pm 0.0000^{\mathrm{a}}$ & - \\
Lead (Pb) & $0.0800 \pm 0.0006^{\mathrm{b}}$ & $0.3900 \pm 0.0058^{\mathrm{c}}$ & $0.0260 \pm 0.0006^{\mathrm{a}}$ & 0.1 \\
\hline
\end{tabular}

Means with different superscript along same row are significantly different at $\mathrm{P}<0.05$ NESREA - National Environmental Standards and Regulatory Enforcement Agency

Fish meat is an important protein source to man (Buikema et al., 1982). The accumulation of heavy metals in fish tissues is dependent upon physicochemical and biological variables such as $\mathrm{pH}$, temperature, hardness, salinity, exposure duration, feeding habits of species and habitat complexity (Zeitoun and Mehana, 2014; Putshaka et al., 2015). The result of the concentrations of TPH and HM in all the fish organs collected from the sampling stations are presented in table 2 . Through bioaccumulation and bio-magnification, large volumes of HM get concentrated in the body of fish since they live primarily in water (Velez and Montoro, 1998) and they are at higher trophic level. The concentrations of all the metals investigated in all the organs of fish at station B were significantly $(\mathrm{P}<0.05)$ higher compared to stations $\mathrm{A}$ and $\mathrm{C}$. TPH was not accumulated in the bone of fish samples from station $\mathrm{C}$ while it had the highest and lowest concentrations in the gills and kidney of samples from stations B and C, respectively. The TPH was higher in the muscle than in the skin and bone. This is similar to the reports of Enuneku et al. (2015) and Al-Ali et al. (2016) who observed higher values of TPH in fish muscles. Samples from station B showed that the liver had the highest concentrations of $\mathrm{Fe}$ and $\mathrm{Zn}$ while the lowest were recorded in the muscle and kidney, respectively; $\mathrm{Cd}$ had highest concentration in the kidney while the liver recorded the lowest concentration. However, Cd was not bioaccumulated in the gills, GIT and liver of fish sampled from stations $A$ and C. Fish samples from station $\mathrm{C}$ did not have any trace of $\mathrm{Ba}$ in the gill, GIT and liver while $\mathrm{Pb}$ was not detected in all the organs except a very trace amount in the liver. The fish were able to regulate the bioaccumulation of these metals because of the chronically elevated 
levels of $\mathrm{Zn}$ (USEPA, 2003). This is due to the fact that there are no known disorders associated with the excessive accumulation of zinc (Vallee and Falchuk, 1993) and its general stable association with macromolecules and coordination flexibility makes it highly adaptable to meet with the needs of proteins and enzymes that carry out various biological functions (Vallee and Auld, 1989, 1990a and 1990b).

The accumulation of the metals in the liver is likely linked to the role of liver in metabolism (Zhao et al., 2012). The physiological role of the liver in blood cells and hemoglobin synthesis gives iron the tendency of accumulating in hepatic tissues (Korkmaz et al., 2012). The pattern of bioaccumulation in the liver has also been observed in a number of other reports on fish species (Rashed, 2001; Dural et al., 2006; Pyle et al., 2005; Storelli et al., 2006; Ploetz et al., 2007; Agah et al., 2009). The resultant effects of these accumulated TPH and HM in humans consuming this fish from Agba stream over time could result into vomiting and diarrhea (Dudkar and Miller, 1999). Similarly, pollutants in fish can severely reduce some vital nutrients in the body of consumers and this may be accountable for declining immune defense, growth delay, reduced physiological abilities, incapacities related with malnutrition and greater occurrence of upper gastro-intestinal cancer (Iyengar and Nair, 2000; Arora et al., 2008).

The result of the bioaccumulation factors (BAF) of total petroleum hydrocarbon and heavy metals in all the fish organs collected from the sampling stations are presented in table 3. The BAF computed in the organs of fish samples collected from station A ranged from 0 for $\mathrm{Cd}$ in the gills, GIT and liver to 687.69 for iron observed in the kidney. For station $\mathrm{B}$, the BAF ranged from 0.01 for TPH in the bone and kidney to 219.4 for $\mathrm{Zn}$ in the liver. The BAF for station $C$ ranged from 0 for TPH in the bone; $\mathrm{Cd}$ and $\mathrm{Ba}$ in the gills, GIT and liver; and $\mathrm{Pb}$ in all the organs to 2832.6 for iron in the liver. The highest BAF values were gotten for tissues from station $C$ (Table 3) which is the control station that had the lowest concentrations of TPH and HM (Table 2). The values obtained at the control site confirmed that BAF values were highest at the lowest exposure concentrations and decreased as concentrations increased (McGeer et al., 2003). Similar reports of inverse relationship of metal concentrations and BAFs were given by different authors (Yehia and Sebaee, 2012; Asante et al., 2014; Muir et al., 2017). Body burdens tend to increase (i.e., bioaccumulation occurs) as metal exposure concentration increases, but at a relatively slower rate (USEPA, 2003). 
Table 2: Concentration of Heavy Metals and Total Petroleum Hydrocarbon in the Tissues of Pellonula afzeliusi from the Agba Stream and Oyun Dam

\begin{tabular}{|c|c|c|c|c|}
\hline \multicolumn{5}{|c|}{ Sampling Locations } \\
\hline Parameters & Tissues & Station A & Station B & Station C \\
\hline \multirow{7}{*}{ TPH (mg/g) } & Skin & $0.0063 \pm 0.0001^{\mathrm{a}}$ & $0.0079 \pm 0.0001^{\mathrm{c}}$ & $0.0042 \pm 0.0002^{b}$ \\
\hline & Bone & $0.0011 \pm 0.0017^{b}$ & $0.0015 \pm 0.000^{\mathrm{b}}$ & $0.0000 \pm 0.0000^{\mathrm{a}}$ \\
\hline & Muscle & $0.0107 \pm 0.0020^{\mathrm{b}}$ & $0.0123 \pm 0.00051^{\mathrm{c}}$ & $0.0092 \pm 0.0004^{\mathrm{a}}$ \\
\hline & Gills & $0.0122 \pm 0.0007^{b}$ & $0.0145 \pm 0.0003^{c}$ & $0.0099 \pm 0.0005^{\mathrm{a}}$ \\
\hline & GIT & $0.0113 \pm 0.0009^{\mathrm{ab}}$ & $0.0128 \pm 0.0004^{b}$ & $0.0107 \pm 0.0002^{\mathrm{a}}$ \\
\hline & Liver & $0.0069 \pm 0.0006^{\mathrm{b}}$ & $0.0071 \pm 0.0006^{\mathrm{b}}$ & $0.0049 \pm 0.0001^{\mathrm{a}}$ \\
\hline & Kidney & $0.0008 \pm 0.0001^{\mathrm{b}}$ & $0.0008 \pm 0.0001^{\mathrm{b}}$ & $0.0006 \pm 0.0000^{\mathrm{a}}$ \\
\hline \multirow{7}{*}{$\mathrm{Fe}(\mathrm{mg} / \mathrm{g})$} & Skin & $0.0798 \pm 0.0034^{\mathrm{b}}$ & $0.0906 \pm 0.0004^{\mathrm{c}}$ & $0.0337 \pm 0.0004^{\mathrm{a}}$ \\
\hline & Bone & $0.0325 \pm 0.0009^{\mathrm{ab}}$ & $0.0649 \pm 0.0001^{b}$ & $0.0213 \pm 0.0001^{\mathrm{a}}$ \\
\hline & Muscle & $0.0273 \pm 0.0029^{\mathrm{b}}$ & $0.0408 \pm 0.0003^{\mathrm{c}}$ & $0.0139 \pm 0.0001^{\mathrm{a}}$ \\
\hline & Gills & $0.0435 \pm 0.0007^{\mathrm{b}}$ & $0.0926 \pm 0.0004^{\mathrm{c}}$ & $0.0280 \pm 0.0002^{\mathrm{a}}$ \\
\hline & GIT & $0.0352 \pm 0.0016^{\mathrm{b}}$ & $0.0918 \pm 0.0012^{\mathrm{c}}$ & $0.0231 \pm 0.0012^{\mathrm{a}}$ \\
\hline & Liver & $0.0841 \pm 0.0021^{\mathrm{a}}$ & $0.1532 \pm 0.0006^{\mathrm{c}}$ & $0.0643 \pm 0.0003^{b}$ \\
\hline & Kidney & $0.0894 \pm 0.0015^{\mathrm{b}}$ & $0.0966 \pm 0.0002^{\mathrm{c}}$ & $0.0425 \pm 0.0005^{a}$ \\
\hline \multirow{7}{*}{$\mathrm{Zn}(\mathrm{mg} / \mathrm{g})$} & Skin & $0.0835 \pm 0.0018^{\mathrm{b}}$ & $0.1443 \pm 0.0004^{\mathrm{c}}$ & $0.0718 \pm 0.0003^{\mathrm{a}}$ \\
\hline & Bone & $0.0883 \pm 0.0021^{b}$ & $0.1495 \pm 0.0021^{\mathrm{c}}$ & $0.0668 \pm 0.0002^{\mathrm{a}}$ \\
\hline & Muscle & $0.0882 \pm 0.0026^{\mathrm{a}}$ & $0.1460 \pm 0.0028^{\mathrm{b}}$ & $0.0875 \pm 0.0004^{a}$ \\
\hline & Gills & $0.0977 \pm 0.0027^{a}$ & $0.1418 \pm 0.0004^{\mathrm{b}}$ & $0.0967 \pm 0.0003^{a}$ \\
\hline & GIT & $0.0937 \pm 0.0046^{\mathrm{a}}$ & $0.1416 \pm 0.0008^{b}$ & $0.0847 \pm 0.0025^{a}$ \\
\hline & Liver & $0.0773 \pm 0.0095^{\mathrm{a}}$ & $0.2194 \pm 0.0020^{\mathrm{b}}$ & $0.0709 \pm 0.0008^{a}$ \\
\hline & Kidney & $0.0687 \pm 0.0013^{\mathrm{a}}$ & $0.1224 \pm 0.0004^{b}$ & $0.0685 \pm 0.0005^{\mathrm{a}}$ \\
\hline \multirow{7}{*}{$\mathrm{Cd}(\mathrm{mg} / \mathrm{g})$} & Skin & $0.0005 \pm 0.0005^{\mathrm{a}}$ & $0.0088 \pm 0.0006^{\mathrm{b}}$ & $0.0001 \pm 0.0009^{a}$ \\
\hline & Bone & $0.0005 \pm 0.0003^{\mathrm{a}}$ & $0.0119 \pm 0.0002^{\mathrm{b}}$ & $0.0001 \pm 0.0002^{a}$ \\
\hline & Muscle & $0.0003 \pm 0.0007^{\mathrm{a}}$ & $0.0098 \pm 0.0006^{\mathrm{b}}$ & $0.0001 \pm 0.0003^{a}$ \\
\hline & Gills & $0.0000 \pm 0.0000^{\mathrm{a}}$ & $0.0007 \pm 0.0001^{\mathrm{a}}$ & $0.0000 \pm 0.0000^{\mathrm{a}}$ \\
\hline & GIT & $0.0000 \pm 0.0000^{\mathrm{a}}$ & $0.0006 \pm 0.0000^{\mathrm{a}}$ & $0.0000 \pm 0.0000^{a}$ \\
\hline & Liver & $0.0000 \pm 0.0000^{\mathrm{a}}$ & $0.0005 \pm 0.0000^{a}$ & $0.0000 \pm 0.0000^{a}$ \\
\hline & Kidney & $0.0002 \pm 0.0000^{\mathrm{a}}$ & $0.0131 \pm 0.0007^{b}$ & $0.0001 \pm 0.0000^{a}$ \\
\hline \multirow{7}{*}{$\mathrm{Ba}(\mathrm{mg} / \mathrm{g})$} & Skin & $0.0006 \pm 0.0002^{\mathrm{b}}$ & $0.0100 \pm 0.0003^{\mathrm{c}}$ & $0.0001 \pm 0.0002^{a}$ \\
\hline & Bone & $0.0009 \pm 0.0002^{\mathrm{a}}$ & $0.0280 \pm 0.0007 \mathrm{~b}$ & $0.0001 \pm 0.0007 \mathrm{a}$ \\
\hline & Muscle & $0.0004 \pm 0.0009^{\mathrm{a}}$ & $0.0090 \pm 0.0006^{\mathrm{b}}$ & $0.0001 \pm 0.0007^{a}$ \\
\hline & Gills & $0.0002 \pm 0.0000^{\mathrm{a}}$ & $0.0091 \pm 0.0002^{\mathrm{b}}$ & $0.0000 \pm 0.0000^{\mathrm{a}}$ \\
\hline & GIT & $0.0001 \pm 0.0000^{\mathrm{a}}$ & $0.0011 \pm 0.0000^{\mathrm{b}}$ & $0.0000 \pm 0.0000^{\mathrm{a}}$ \\
\hline & Liver & $0.0001 \pm 0.0000^{\mathrm{a}}$ & $0.0034 \pm 0.0003^{b}$ & $0.0000 \pm 0.0000^{\mathrm{a}}$ \\
\hline & Kidney & $0.0005 \pm 0.0000^{\mathrm{a}}$ & $0.0109 \pm 0.0009^{\mathrm{b}}$ & $0.0001 \pm 0.0000^{\mathrm{a}}$ \\
\hline \multirow{7}{*}{$\mathrm{Pb}(\mathrm{mg} / \mathrm{g})$} & Skin & $0.0002 \pm 0.0006^{\mathrm{a}}$ & $0.0009 \pm 0.0003^{\mathrm{b}}$ & $0.0000 \pm 0.0000^{\mathrm{a}}$ \\
\hline & Bone & $0.0007 \pm 0.0002^{\mathrm{a}}$ & $0.0087 \pm 0.0002^{\mathrm{b}}$ & $0.0000 \pm 0.0000^{\mathrm{a}}$ \\
\hline & Muscle & $0.0001 \pm 0.0003^{\mathrm{a}}$ & $0.0001 \pm 0.0002^{\mathrm{a}}$ & $0.0000 \pm 0.0000^{a}$ \\
\hline & Gills & $0.0003 \pm 0.0000^{\mathrm{b}}$ & $0.0013 \pm 0.0000^{\mathrm{c}}$ & $0.0000 \pm 0.0000^{\mathrm{a}}$ \\
\hline & GIT & $0.0002 \pm 0.0002^{\mathrm{b}}$ & $0.0009 \pm 0.0000^{c}$ & $0.0000 \pm 0.0000^{\mathrm{a}}$ \\
\hline & Liver & $0.0001 \pm 0.0000^{\mathrm{a}}$ & $0.0059 \pm 0.0007 \mathrm{~b}$ & $0.0001 \pm 0.0000^{\mathrm{a}}$ \\
\hline & Kidney & $0.0000 \pm 0.0000^{\mathrm{a}}$ & $0.0008 \pm 0.0000^{\mathrm{b}}$ & $0.0000 \pm 0.0000^{\mathrm{a}}$ \\
\hline
\end{tabular}

Means with different superscript along same row are significantly different at $\mathrm{P}<0.05$. 
Table 3: Bioaccumulation Factors of Total Petroleum Hydrocarbon and Heavy Metals in the Tissues of Pellonula afzeliusi Collected from the Agba Stream and Oyun Dam

\begin{tabular}{|c|c|c|c|c|c|c|c|}
\hline \multicolumn{8}{|c|}{ Parameters } \\
\hline Tissues & Stations & TPH & $\mathrm{Fe}$ & $\mathrm{Zn}$ & Cd & $\mathbf{B a}$ & $\mathrm{Pb}$ \\
\hline Skin & $\begin{array}{l}\text { A } \\
\text { B } \\
\text { C }\end{array}$ & $\begin{array}{l}0.05 \\
0.05 \\
0.46\end{array}$ & $\begin{array}{c}613.85 \\
112.31 \\
1484.58\end{array}$ & $\begin{array}{c}124.63 \\
144.3 \\
598.33 \\
\end{array}$ & $\begin{array}{l}5.56 \\
7.33 \\
7.69\end{array}$ & $\begin{array}{c}2 \\
10.92 \\
1\end{array}$ & $\begin{array}{c}2.5 \\
2.31 \\
0\end{array}$ \\
\hline Bone & $\begin{array}{l}\text { A } \\
\text { B } \\
\text { C }\end{array}$ & $\begin{array}{c}0.01 \\
0.01 \\
0\end{array}$ & $\begin{array}{c}250 \\
80.45 \\
938.33\end{array}$ & $\begin{array}{c}131.79 \\
149.5 \\
556.67\end{array}$ & $\begin{array}{l}5.56 \\
9.92 \\
7.69\end{array}$ & $\begin{array}{c}3 \\
53.85 \\
1\end{array}$ & $\begin{array}{c}8.75 \\
22.31 \\
0\end{array}$ \\
\hline Muscle & $\begin{array}{l}\text { A } \\
\text { B } \\
\text { C }\end{array}$ & $\begin{array}{l}0.08 \\
0.08 \\
1.01 \\
\end{array}$ & $\begin{array}{c}210 \\
50.58 \\
612.34 \\
\end{array}$ & $\begin{array}{c}131.64 \\
146 \\
729.17 \\
\end{array}$ & $\begin{array}{l}3.33 \\
8.17 \\
7.69 \\
\end{array}$ & $\begin{array}{c}1.33 \\
17.31 \\
1 \\
\end{array}$ & $\begin{array}{c}1.25 \\
0.26 \\
0 \\
\end{array}$ \\
\hline Gills & $\begin{array}{l}\text { A } \\
\text { B } \\
\text { C }\end{array}$ & $\begin{array}{l}0.09 \\
0.09 \\
1.09\end{array}$ & $\begin{array}{c}334.62 \\
114.79 \\
1233.48\end{array}$ & $\begin{array}{c}145.82 \\
141.8 \\
805.83\end{array}$ & $\begin{array}{c}0 \\
0.58 \\
0\end{array}$ & $\begin{array}{c}0.67 \\
17.5 \\
0\end{array}$ & $\begin{array}{c}3.75 \\
3.33 \\
0\end{array}$ \\
\hline GIT & $\begin{array}{l}\text { A } \\
\text { B } \\
\text { C }\end{array}$ & $\begin{array}{l}0.08 \\
0.08 \\
1.18 \\
\end{array}$ & $\begin{array}{c}270.77 \\
113.8 \\
1017.62\end{array}$ & $\begin{array}{c}139.85 \\
141.6 \\
705.83\end{array}$ & $\begin{array}{c}0 \\
0.5 \\
0\end{array}$ & $\begin{array}{c}0.33 \\
2.12 \\
0\end{array}$ & $\begin{array}{c}2.5 \\
2.31 \\
0\end{array}$ \\
\hline Liver & $\begin{array}{l}\text { A } \\
\text { B } \\
\text { C }\end{array}$ & $\begin{array}{l}0.05 \\
0.05 \\
0.54\end{array}$ & $\begin{array}{l}646.92 \\
189.91 \\
2832.6\end{array}$ & $\begin{array}{c}115.37 \\
219.4 \\
590.83\end{array}$ & $\begin{array}{c}0 \\
0.42 \\
0\end{array}$ & $\begin{array}{c}0.33 \\
6.54 \\
0 \\
\end{array}$ & $\begin{array}{c}1.25 \\
15.13 \\
3.85\end{array}$ \\
\hline Kidney & $\begin{array}{l}\text { A } \\
\text { B } \\
\text { C }\end{array}$ & $\begin{array}{l}0.01 \\
0.01 \\
0.07\end{array}$ & $\begin{array}{c}687.69 \\
119.75 \\
1872.25\end{array}$ & $\begin{array}{c}102.54 \\
122.4 \\
570.83 \\
\end{array}$ & $\begin{array}{c}2.22 \\
10.92 \\
7.69\end{array}$ & $\begin{array}{c}1.67 \\
20.96 \\
1\end{array}$ & $\begin{array}{c}0 \\
2.05 \\
0\end{array}$ \\
\hline
\end{tabular}

According to waste minimization prioritization tool (WMPT) scoring (USEPA, 2003), the BAF values obtained from this study indicated that total petroleum hydrocarbon, cadmium, barium and lead were of low concern, zinc ranged from low to medium concern, and iron ranged from low, medium to high concern.

\section{CONCLUSION}

The environmental quality assessment of the stream indicated heavy pollution burden in station $\mathrm{B}$ as a result of auto-mechanic workshop along the stream with lower pollution burden in station $\mathrm{C}$ (the control site). This calls for attention in ensuring ecological restoration and prevention of further discharge of auto-mobile wastes into the stream through management. This will ensure preservation and sustainability of the ecosystem, and fish in this stream will pose less health risk to humans consuming them.

\section{REFERENCES}

Abioye, O.P., Agamuthu, P. and Abdul Aziz, A.R. 2012. Biodegradation of used motor oil in soil using organic waste amendments. Biotechnology Resource Institute, 7(8): 230-238.
Adelekan, B.A. and Abegunde, K.D. 2011. Heavy metals contamination of soil and groundwater at automobile mechanic villages in Ibadan, Nigeria. International Journal of Physical Sciences, 6(5): 1045-1058.

Adewoyin, O.A., Hassan, A.T. and Aladesida, A.A. 2013. The impacts of auto-mechanic workshops on soil and groundwater in Ibadan metropolis. African Journal of Environmental Science and Technology, 7(9): 891-898.

Agah, H., Leermakers, M., Elskens, M., Fatemi S.M.R. and Baeyens, W.2009. Accumulation of trace metals in the muscle and liver tissues of five fish species from the Persian Gulf. Environmental Monitoring and Assessment, 157: 499-514.

Al-Ali, B.S, Al-Bidhani, M.F., Al-Khion, D.D, AlNagar, G.A, Al-Saad, H.T., Khwadem, A.A., Zeidan, A.M., Mahdi, S., Hantoush, A.A. 2016. Environmental assessment of petroleum hydrocarbons in fish species from North-West Arabian Gulf. Research Journal of Pharmacentical, Biological and Chemical Sciences, 4(1): 126-134.

Al-Attar, A.M. 2005. Changes in haematological 
parameters of the fish, Oreochromis niloticus treated with sublethal concentrations of cadmium. Pakistan Journal of Biological Sciences, 8(3): 421-424.

American Public Health Association (APHA), American Water Works Association, and Water Pollution Control Federation 2012. Standard methods for the examination of water and wastewater. $22^{\text {nd }}$ ed. American Public Health Association, American Water Works Association, and Water Pollution Control Federation, Washington, D.C. 1360 pp.

Arora, M., Kiran, B., Rani, A., Kaur, B. and Mittal, N. 2008. Heavy metals accumulation in vegetables irrigated with water from different sources. Food Chemistry, 111(4): 811-815.

Asante, F., Agbeko, E., Addae, G. and Quainoo, A.K. 2014. Bioaccumulation of heavy metals in water, sediments and tissues of some selected fishes from Red Volta, Nangodi in the Upper East region of Ghana. British Journal of Applied Science and Technology, 4(4): 594-603.

Bawuro, A.A., Voegborlo, R.B. and Adimado, A.A. 2018. Bioaccumulation of heavy metals in somtissues of fish in Lake Geriyo, Adamawa state, Nigeria. Journal of Environment and Public Health. Article ID 1854892.

Buikema (Jr), A.L., Niederlehner, B.R. and Cairns (Jr), J. 1982. Biological monitoring part IVToxicity testing. Water Research, 16 (3): 239262.

Campbell, L.M., Norstrom, R.J., Hobson, K.A., Muir, D.C.G., Backus, S. and Fisk, A.T. 2005. Mercury and other trace elements in a pelagic Arctic Marine food web, (Northwater Polynya, Baffin Bay). Science of the TotalEnvironment, 351-352:247-263.

Dudka, S. and Miller, W.P. 1999. Permissible concentration of arsenic and lead in soils based on risk assessment. Water, Air and Soil Pollution, 113: 127-132.

Du Preez, H.H. and Steyn G.J. 1992. A preliminary investigation of the concentration of selected metals in the tissues and organs of the tiger fish (Hydrocynus vittatus) from the Olifants River, Kruger National Park, South Africa. Water $S A, 18(2): 131-136$.
Dural, M., Göksu, M.Z., Ozak, A.A. and Derici, B. 2006. Bioaccumulation of some heavy metals in different tissues of Dicentrachus labrax L., 1758, Sparus aurata L., 1758, and Mugil cephalus L., 1758 from the Camlik lagoon of the eastern coast of Mediterranean (Turkey). Environmental Monitoring and Assessment, 118 (1-3): 65-74.

EGASPIN (Environmental Guidelines and Standards for the Petroleum Industry in Nigeria), Revised Edition, Department of Petroleum Resources (DPR). 2002. 314pp.

El-Nagger, A.M., Mohamoud, S.A. and Tayel, S.I. 2009. Bioaccumulation of some heavy metals and histopathological alterations in liver of Oreochromis niloticus in relation to water quality at different localities along the River Nile, Egypt. World Journal of Fish and Marine Sciences, 1(2): 105-114.

Enuneku, A.A., Ainerua, M., Erhunmwunse, N.O. and Osakue, O.E. 2015. Total petroleum hydrocarbons in organs of commercially available fish; Trachurus trecae (Cadenat, 1949) from Oliha market, Benin City, Nigeria. Ife Journal of Science, 17:383-393.

Ezenwaji, H.M.G. and Offiah, F.N. 2004. The Biology of Pellonula leonensis Boulenger, 1916 (Osteichthyes: Clupidae) in Anambra River, Nigeria. Bio-Research, 1(2): 33-50.

Froese, R. and Pauly, D. Editors. 2019.FishBase. www.fishbase.org, version (12/2019). Accessed on 20/06/2020.

Goodwin, T.H., Young, A.R., Holmes, M.G.R., Old, G.H., Hewitt, N., Leeks, G.J.L., Packman, C.J. and Smith, B.P.G 2003. The temporal and spatial variability of sediment transport and yields within the Bradford Beck catchment, West Yorkshire. Science of the Total Environment, 314-316: 475-494.

Horsfall, M. J. (2011). Advanced Environmental Chemistry (1st ed.). Port-Harcourt: La Limestar printer.

Idodo-Umeh, G. 2003. Freshwater fishes of Nigeria: Taxonomy, ecological notes, diet and utilization. Idodo Umeh Publisher, Benin, Nigeria.

Ikpe, E.E., Akpakpan, A.E., Nsi, E.W. and Ekanem, A.N. 2016. Determination of 
the level of petroleum hydrocarbon in water, fishes and plants from part of river Ethiope, Oghara in Delta State, Nigeria. International Journal for Research in Applied and Natural Science, 2 (9): 01-10.

Ikusemiju, K., Oki, A.A. and Graham-Douglas M. 1983. The Biology of an estuarine population of the clupeid Pellonula af zeluisi (Johnels) in Lagos Lagoon, Nigeria. Hydrobiologia, 102: 55-59.

Iyengar, G.V. and Nair, P.P. 2000. Global outlook on nutrition and the environment; meeting the challenges of the next millennium. Science of the Total Environment, 249(1-3): 331-346.

Izegaegbe, J.I. and Oloye, F.F. 2017. Assessment of selected metals in the muscle and liver of the African catfish (Clarias gariepinus) collected from Ilushi river, Ilushi, Edo state, Nigeria. Ife Journal of Science, 19:1-5.

Korkmaz, G.F, Keser, R., Akçay, N. and Dizman, S. 2012. Radioactivity and heavy metal concentrations of some commercial fish species consumed in the Black Sea Region of Turkey. Chemosphere, 87(4), 356-361.

McGeer, J.C., Brix, K.V., Skeaff, J.M., DeForest, D.K., Brigham, S.I., Adams, W.J. and Green, A. 2003. Inverse relationship between bioconcentration factor and exposure concentration for metals: implications for hazard assessment in the aquatic environment. Environmental Toxicology and Chemistry, 22: 1017- 1037.

Muir, D., Simmons, D., Wang, X. Peart, T. Villella, M, Miller, J. and Sherry, J. 2017. Bioaccumulation of pharmaceuticals and personal care product chemicals in fish exposed to wastewater effluent in an urban wetland. Scientific Reports 7(1), Article 16999.

National Environmental Standards and Regulatory Agency (NESREA). National Environmental (Surface and groundwater control) regulations (2011).

Nevoh, G.O., Akhionbare, S.M.O. and Uzoma, H.C. 2015. Water quality aspects of river Okpokain relation to watershed activities. Resources and Environment, 5(4): 124-133.

Oladipo, S.O., Mustapha, M.K., Suleiman, L.K. and Anifowoshe, A.T. 2018. Fish compositionand d i v e r s i t y assessment of Apodu reservoir, Malete, Nigeria. International Journal of Fisheries and Aquatic Studies, 6(2): 89-93.

Olaifa, F.G., Olaifa, A.K. and Onwude, T.E. 2004. Lethal and sub-lethal effects of copper to the African cat fish (Clarias gariepinus). African Journal of Biomedical Research, 7(2): 65-70.

Olaosebikan, B.D. and Raji, A. 1998. Field guide to Nigerian freshwater fishes. Federal College of Freshwater Fisheries Technology, New Bussa.

Papagiannis, I., Kagalou, I., Leonardos, J., Petridis, D. and Kalfakaou, V. 2004. Copper and zinc in four freshwater fish species from Lake Pamvotis (Greece). Environment International, 30: 357-362.

Ploetz, D.M., Fitts, B.E. and Rice, T.M. 2007. Differential accumulation of heavy metals in muscles and liver of a marine fish (King Mackerel, Scomberomorus cavalla cuvier) from the Northern Gulf of Mexico, USA Bulletin of Environmental Contamination and Toxicology, 78(2): 134-137.

Popoola, O.O. and Ayodele, F.O. 2016. Effects of automobile repair workshop on water qualityof selected area in Ado-Ekiti, Nigeria. Journal of Multidisciplinary Engineering Science and Technology, 3(8): 5363-5365.

Putshaka, J.D., Akyengo, O., Yakubu, A. and Adejube, A.A.H. 2015. Bioaccumulation of heavy metals in fish (Tilapia zilli) and Bullfrog (Pyxicephalus edulis) from River Challawa, Kano State, Nigeria. International Journal of Ecological Science and EnvironmentalEngineering, 2: 30-34.

Pyle, G.G., Rajotte, J.W. and Couture, P. 2005. Effects of industrial metals on wild fish populations along a metal contamination gradient. Ecotoxicology and Environmental Safety, 61(3): 287-312.

Rashed, M.N. 2001. Monitoring of environmental heavy metals in fish from Nasser Lake. Environ Int, 27(1), 27-33.

Schwab, A.P., Su, J., Wetzel, S. Pekarek, S. and Banks, M.K. 1999. Extraction of petroleum hydrocarbons from soil by mechanical shaking. Environment International, 33:1940-1945. 
Storelli, M.M., Barone, G., Storelli, A. and Marcotrigiano, G.O. 2006. Trace metals in tissues of Mugilids (Mugil auratus, Mugil capito and Mugil labrosus) from the Mediterranean Sea. Bulletin of Environmental Contamination and Toxicology, 77: 43-50.

USEPA (United States Environmental Protection Agency). 2003. Issue paper on the bioavailability and bioaccumulation of metals. US EPA Archive Document.

USEPA (United States Environmental Protection Agency). 2010. "EPA Method 1664, Revision B: n-Hexane extractable material (HEM; oil and grease) and silica gel treated n-hexane extractable material (SGT-HEM; non-polar material) by extraction and gravimetry," Tech. Rep. EPA-821-R-10-001.

Utang, P.B., Eludoyin, O.S. and Ijekeye, C.L. 2013. Impacts of automobile workshops on heavy metals concentrations of urban soils in Obio/Akpor LGA, Rivers State, Nigeria. African Journal of Agricultural Research, 8(26):3476-3482.

Vallee, B.L. and Auld, D.S. 1989. Short and long spacer sequences and other structural features of zinc binding sites in zinc enzymes. FEBS Letters, 257 (1): 138-140.

Vallee, B.L. and Auld, D.S. 1990a. Zinc coordination, function, and structure of zinc enzymes and other proteins. Biochemistry, 29: 5647-5659.

Vallee, B.L. and Auld, D.S. 1990b. Active-site zinc ligands and activated $\mathrm{H}_{2} \mathrm{O}$ of zinc enzymes. Proceedings of the National Academy of Sciences of the United States of America, 87(1):220-224.

Vallee, B.L. and Falchuk, K.H. 1993. The biochemical basis of zinc physiology. Physiological Reviews, 73(1): 79-118.

Velez, D. and Montoro, R. 1998. Arsenic speciation in manufactured seafood products. Journal of Food Protection, 61: 1240-1245.

Webster, L., Topping, G., Dalgarno, E.J., Moffat, C.F., Webster, L. and Angus, L. 1997. Long term monitoring of polycyclic aromatic hydrocarbons in mussels (Mytilus edulis) following the Braer oil spill Analyst, 122: 1491-1495.

Yehia, H.M. and Sebaee, E.S. 2012. Bioaccumulation of heavy metals in water, sediment and fish (Oreochromis niloticus and Clarias anguillaris), in Rosetta branch of the River Nile, Egypt. African Journal of Biotechnology, 11:14204-14216.

Zeitoun, M.M. and Mehana, E.E. 2014. Impact of water pollution with heavy metals on fish health: Overview and updates. Global Veterinaria, 12:219-231.

Zhao, S., Feng, C., Quan, W., Chen, X., Niu, J. and Shen, Z. 2012. Role of living environments in the accumulation characteristics of heavy metals in fishes and crabs in the Yangtze River Estuary, China. Marine Pollution Bulletin, 64(6): 1163-1171. 